\title{
Aboveground Forest Carbon Stock in Protected Area: A Case Study of Bukit Tigapuluh National Park, Indonesia
}

\author{
Arief Darmawan ${ }^{*}$, Zulfira Warta ${ }^{2}$, Elis Molidena², Alexandra Valla², Muhammad Iqbal Firdaus ${ }^{2}$, \\ Gunardi Djoko Winarno', Bondan Winarno ${ }^{3}$, Teddy Rusolono ${ }^{4}$, Satoshi Tsuyuki ${ }^{5}$ \\ 1)Department of Forestry, Lampung University, Jl. Sumantri Brojonegoro No.1, Bandar Lampung, Indonesia, 35145 \\ 2) WWF Indonesia, Graha Simatupang Tower 2, Jakarta Indonesia, 12430 \\ 3)Forest Research and Development Center, Ministry of Environment and Forestry, Jln.Gunung Batu No.5 Bogor, 16119 \\ 4)Faculty of Forestry and Environment, IPB University, Jl. Raya Dramaga Bogor, West Java, Indonesia, 16680 \\ 5) Graduate School of Agriculture and Life Sciences, The University of Tokyo, 1-1-1 Yayoi, Bunkyo-ku, Tokyo, Japan, 113-0032 \\ * Corresponding author, email: arief.darmawan@fp.unila.ac.id
}

\section{Keywords:}

Forest Carbon Stock

Protected Area

REDD+

Submitted:

20 March 2021

Accepted:

30 October 2021

Published:

12 January 2022

Editor:

Ardaning Nuriliani

\begin{abstract}
The role of protected areas has been expanded into climate change mitigation, specifically on Reducing Emissions from Deforestation and Forest Degradation $(\mathrm{REDD}+)$. A reliable and practical method for measuring, reporting and verifying carbon stock is an essential component for REDD+. This study aims to recognize the characteristic and estimate aboveground forest carbon (AGC) stock in the tropical protected tropical area using a combination of terrestrial forest inventory and spatial data. A 168 cluster plots totaling 33.6 hectares were taken proportionally based on the percentage of forest cover types (dryland primary natural forest/ DPF and dryland secondary natural forest/DSF) using a traditional forest inventory method (more than $5 \mathrm{~cm} \mathrm{dbh}$ ). Results showed that Bukit Tigapuluh National Park secured a significant AGC stock which has been estimated to be 269.2 [247.07; 291.43] tC/ha or 35,823,639 [32,872,312; 38,774,966] tC in total, being stored in approximately 133,051 hectares of the tropical rain forest. This result was higher than other studies in non-protected areas but slightly lower than other studies within protected areas. This finding supported the argument that protected areas possess a higher figure of AGC stock than other forest management units. The high amount of forest carbon biomass in the protected areas shall be very important assets for conducting the role of conservation for REDD+.
\end{abstract}

Copyright: C 2022, J. Tropical Biodiversity Biotechnology (CC BY-SA 4.0)

\section{INTRODUCTION}

The role of protected areas as a valuable tool against the pressures on biodiversity and their related effects on human populations is now well recognized (IUCN 2010). Protected areas vary with respect to governance regimes, and management types, including national parks, nature reserves, wildlife sanctuary, hunting parks and watershed protected forests, among many others (Deguignet et al. 2017; Government of Indonesia 1999). As a world's biodiversity hotspot, Indonesia has established 53 national parks, either terrestrial or aquatic national parks, with a total area of approximately 16 million hectares or about $60 \%$ of the total protected areas in Indonesia (Pusat Data dan Informasi KLHK 2017). Within those areas, nearly 80\% were forested in 
2017, which account for $12 \%$ of the overall natural forest in Indonesia (Pusat Data dan Informasi KLHK 2017). However, these parks are at alarming threat of deforestation and degradation, particularly those in Sumatra Island, despite government willingness to protect them (Luskin et al. 2017; Pramudya et al. 2018; Shah \& Baylis 2015).

The role of protected areas has been expanded to a climate change mitigation, particularly in the tropical countries, which much of the concept embedded in Reducing Emission from Deforestation and Forest Degradation (REDD+) (Harada et al. 2015; Indonesia Forest Climate Alliance (IFCA) 2007). REDD+ is a commitment under UN Framework Convention on Climate Change (UNFCCC) that introduced a mechanism for acquiring an international fund- or credit-based mechanism for reducing carbon emissions and protecting forest ecosystems (Brofeldt et al. 2014; Harada et al. 2015). REDD+ has received enormous interest from developing countries as a potential source of international funding for the forestry sector. Indonesia has been enthusiastic about the REDD+ initiative following the $13^{\text {th }}$ Conference of Parties (COP13) in Bali and has actively participated in the international REDD + negotiations. Protected areas, particularly national parks, became a target area for REDD+ in Indonesia (Harada et al. 2015; Indonesia Forest Climate Alliance (IFCA) 2007).

Technically, REDD + is a carbon payment scheme aiming at mitigating climate change through reducing deforestation, reducing forest degradation, conservation of (existing) forest carbon stocks, sustainable management of forests, and enhancement of forest carbon stocks (e.g. through regeneration and planting in previously forest land) (Gardner et al. 2012; Marshall et al. 2012). Therefore, reliable and practical methods for measuring, reporting and verifying carbon stocks are necessary components of REDD+ (Gardner et al. 2012; Petrokofsky et al. 2012). The IPCC Guideline (IPCC 2006) suggests five carbon pools be included to thoroughly estimate forest carbon stock (i.e. aboveground biomass, belowground biomass, deadwood, litter, and soil carbon). Aboveground biomass (AGB) is the most important carbon pool representing the forest's physical conditions (GOFC-GOLD 2014a; Ministry of Environment and Forestry 2016). Attempts for estimating aboveground tropical forest carbon were mostly related to the type of forest ecosystem (dryland forests, moist forests, peat swamp forests, mangrove forests) and also locations (South East Asia, Africa, South America) (Manuri et al. 2017; Marshall et al. 2012; Yamakura et al. 1986).

Indonesia, through the National Forest Reference Emission Level (FREL) submission to the UNFCCC Secretariat (Ministry of Environment and Forestry 2016), has established a national forest carbon stock divided into seven regions (Sumatra, Kalimantan, Java, Lesser Sunda and Bali, Sulawesi, Maluku, and Papua). This data was claimed to be derived from analyzing the National Forest Inventory data from 1990 to 2013. However, the figures, particularly those in Sumatra (i.e. 135 [125; 145] tC/ha for dry primary forest/ DPF and 85.6 [80.9; 90.3$] \mathrm{tC} /$ ha for dry secondary forest/ DSF) and 
Kalimantan (i.e. 126.6 [121.4; 131.9] tC/ha for DPF and 95.6 [92.3; 98.8] $\mathrm{tC} / \mathrm{ha}$ for DSF) were much lower than the other figures in a similar location (Laumonier et al. 2010; Rutishauser et al. 2013; Yamakura et al. 1986). This disparity shall open a wider window to new forest inventory data, particularly those in more stable natural forests, e.g. in protected areas, to support the existing available figures on forest carbon stock. Additionally, estimation of aboveground forest carbon stock in protected areas is fundamental to invest our knowledge to address the role of conservation activity in REDD+, aside from their high biodiversity circumstance.

The present study aims to help fill our gap in knowledge on: (i) the characteristic of forest stands and aboveground forest carbon stocks in a protected area using terrestrial forest inventory; and (ii) estimating the total aboveground forest carbon stock in a protected area using a combination of spatial data and terrestrial forest inventory. We hypothesized that the protected area possessed a relatively higher figure of carbon stocks than the forest under a different type of management, so the role of conservation for carbon stock in a protected area as well as the need for significant activities to maintain this high carbon stock will be demonstrated.

\section{METHODS}

\section{Study Area}

The study area is located within Bukit Tigapuluh National Park (BTNP), Indonesia. Geographically located between E102013' - E102046' and S00²' S01018', BTNP is 144,223 hectares of National Park in Eastern Sumatra, consisting of tropical lowland to a hilly undulating forest on mineral soil (Figure 1) at an altitude between 60 to $843 \mathrm{~m}$ asl. The climate in Bukit Tigapuluh National Park is a typical of tropical rainforest, i.e. always wet even though it also experiences a dry season with an average rainfall of 2,577 $\mathrm{mm}$ per year. The temperature of this area is in the range between $20.8^{0}-33^{0}$ C. The National Park was established in 1995 after timber concessions had been issued in this forest block. This Park is famous as the last shelter for endangered species such as the Sumatran orangutan, Sumatran tiger, Sumatran elephant, Asian tapir, and many endangered bird species. Unfortunately, this vital ecosystem is threatened by illegal logging, illegal farming, mining, and poaching (Bukit Tigapuluh Wildlife Protection Unit 2017). The Park is also inhabited by indigenous peoples of the Orang Rimba (also called Kubu) and Talang Mamak tribes. The Talang Mamak is a sedentary tribe living only in Bukit Tigapuluh National Park (referred to as the Bukit Tigapuluh landscape). The Orang Rimba people are nomadic because of death, avoiding enemies, and shifting cultivation. The Kubu communities scatter in and around the forest, in huts with walls made of bark and roofs made of leaves. They live in small groups to facilitate mobility and migrate through natural forests depending on forest products and river for their existence (Sitompul \& Pratje 2009). The surrounding indigenous peoples (especially the Talang Mamak Tribe) believe that the hills and plants in the national park have magi- 


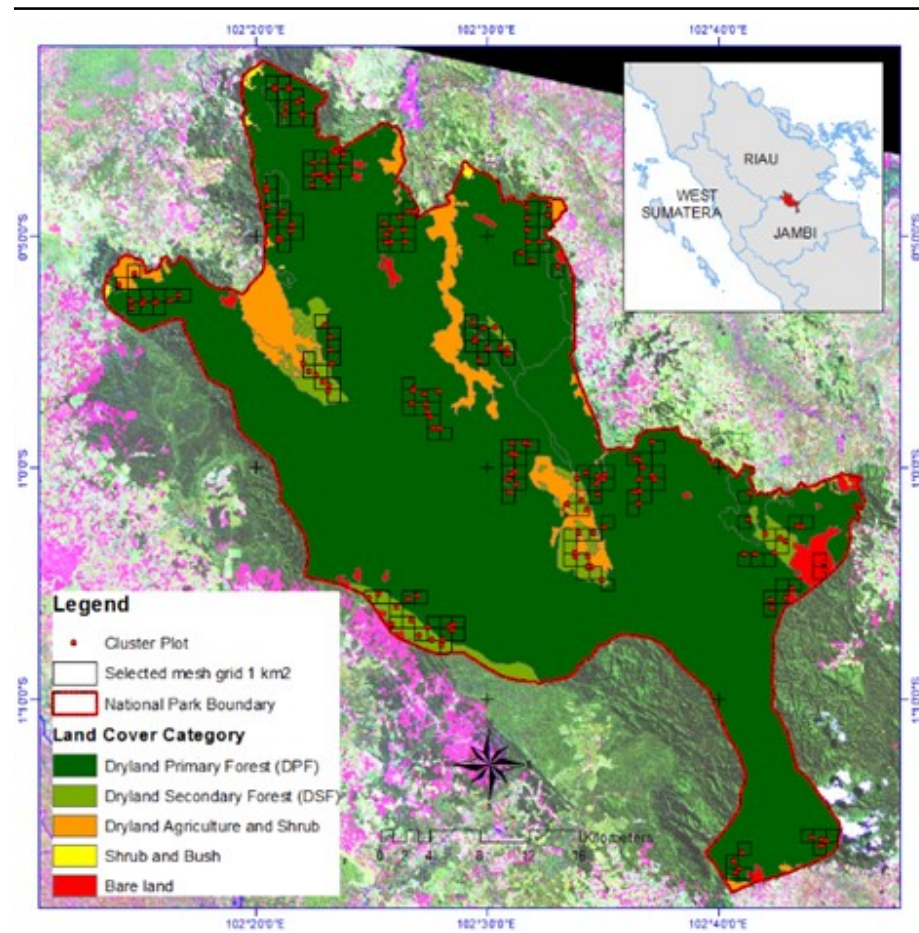

(a)

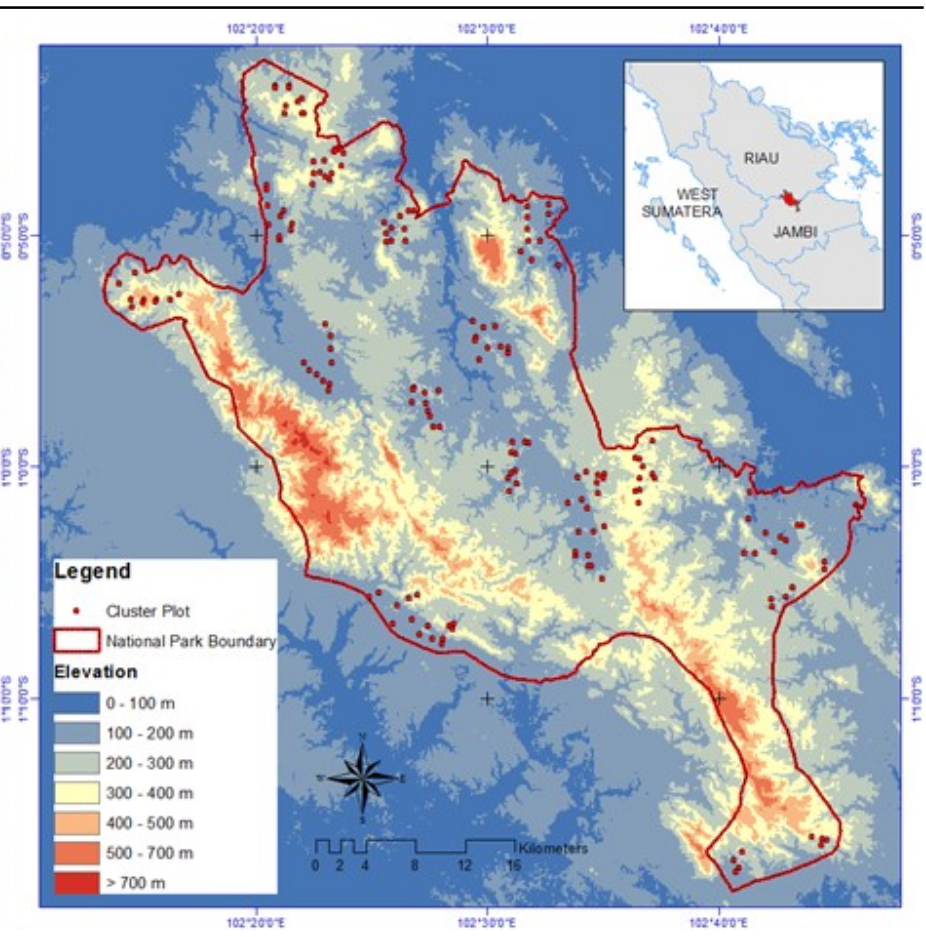

(b)

Figure 1. (a) The study area of Bukit Tigapuluh National Park (red line) and the location of the 168 cluster plots, which was selected purposively based on the forest types; (b) and overlaid to the DEM.

cal powers in their lives, so that they indirectly participate actively in maintaining and protecting the hills and plants in the national park.

\section{Data Collection}

One hundred sixty-eight cluster plots were taken proportionally based on the area percentage of forest cover types (dryland primary forest/DPF and dryland secondary forest/DSF), following a virtual mesh grid of $1 \mathrm{~km}^{2}$ established in the study area (Figure 1). One cluster plot was established within one selected mesh grid regarding forest cover types and access factors. One cluster plot consists of five plots of $400 \mathrm{~m}^{2}$ size (in total 2,000 $\mathrm{m}^{2}$ ) with an arrangement as depicted in Figure 2. This cluster plot is a modification of the conventional single plot of $400 \mathrm{~m}^{2}$ (BSN 2011) or $10,000 \mathrm{~m}^{2}$ (FAO 2007). The reason for choosing a cluster plot is that the larger the area of the sample plot, the greater the proportion of total variation that falls within the plot, and as a result the smaller the standard errors (Baraloto et al. 2013; Henttonen \& Kangas 2015; Picard et al. 2018). Thus, the cluster plot was designed for compromising the larger sample plot's need and complying with the national standard.

We limit our analysis for aboveground biomass and necromass (deadwood) since these carbon pools account for more than $75 \%$ of the total forest biomass in mineral soil (GOFC-GOLD 2014b; Manuri et al. 2016; Ministry of Environment and Forestry 2016). In this study, aboveground biomass and deadwood in carbon estimates were combined and called aboveground forest carbon (AGC, in $\mathrm{tC} / \mathrm{ha}$ ). We omit other carbon pools (i.e. be- 


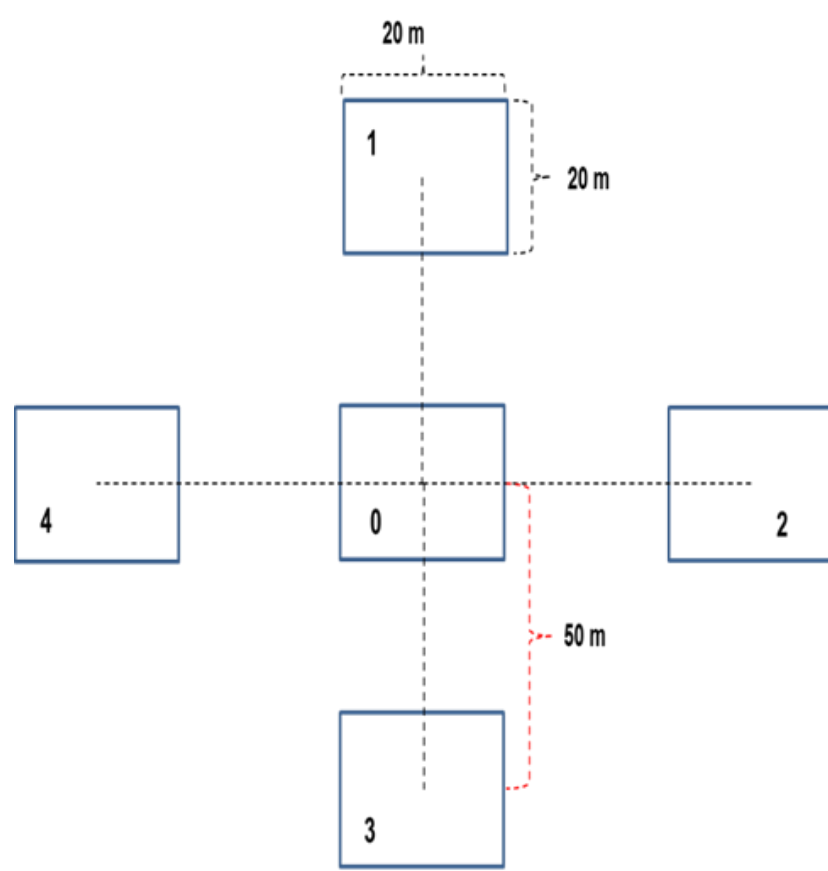

(a)

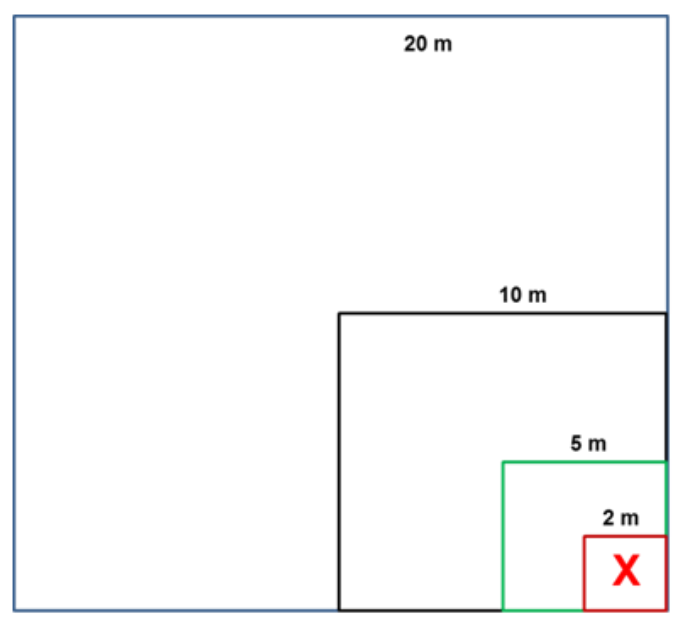

(b)

Figure 2. (a) The arrangement of plots in a cluster plot, the distance of center plot and the side plots was $50 \mathrm{~m}$; (b) Each plot was comprised of subplots of $400 \mathrm{~m}^{2}, 100 \mathrm{~m}^{2}$ and $25 \mathrm{~m}^{2}$.

lowground biomass, litter, and soil carbon) because the study area located on the mineral soil where the fraction of soil carbon is mostly less than $20 \%$ and belowground biomass is mostly estimated through a relationship to aboveground biomass as indicated by (GOFC-GOLD 2014b), which does not have critical influence to the variation of data.

The $400 \mathrm{~m}^{2}$ sub-plot consists of $400 \mathrm{~m}^{2}, 100 \mathrm{~m}^{2}$ and $25 \mathrm{~m}^{2}$ of plots to record the diameter at breast height (dbh) of the tree (greater than or equal to $20 \mathrm{~cm} \mathrm{dbh}$ ), pole (greater than or equal to $10 \mathrm{~cm}$ dbh and less than $20 \mathrm{~cm}$ $\mathrm{dbh}$ ) and sapling (greater than or equal to $5 \mathrm{~cm}$ dbh and less than $10 \mathrm{~cm} \mathrm{dbh}$ ) plant categories, respectively. When the tree was buttressed, the tree diameter was measured approximately $20 \mathrm{~cm}$ above the buttress. The dbh of deadwood was also recorded within $400 \mathrm{~m}^{2}$ plot using standing deadwood categories (BSN 2011), i.e. slight (dead tree without leaves, 0.9 carbon offset factor), moderate (dead tree without leaves and twigs, 0.8 carbon offset factor), and intense (dead tree without leaves, twigs and branches, 0.7 carbon offset factor) as depicted in Figure 3. Downed deadwood was planned to be measured, but we did not find it during the field measurement. In total, a 33.6 hectare of plots was measured from November 2016 to July 2017. A supporting smartphone application was used to assist the surveyor in capturing locations' coordinates and taking on-site photos heading north, east, south, west and looking upward for each cluster plot.

The 2014's land cover data of BTNP on 1:250,000 scales was collected from the Ministry of Environment and Forestry. This data was modified by referring to the 2016 Landsat 8 Image to get the newest condition of land cover so that it relatively parallel to the time of terrestrial forest inventory was carried out (Figure 1). 


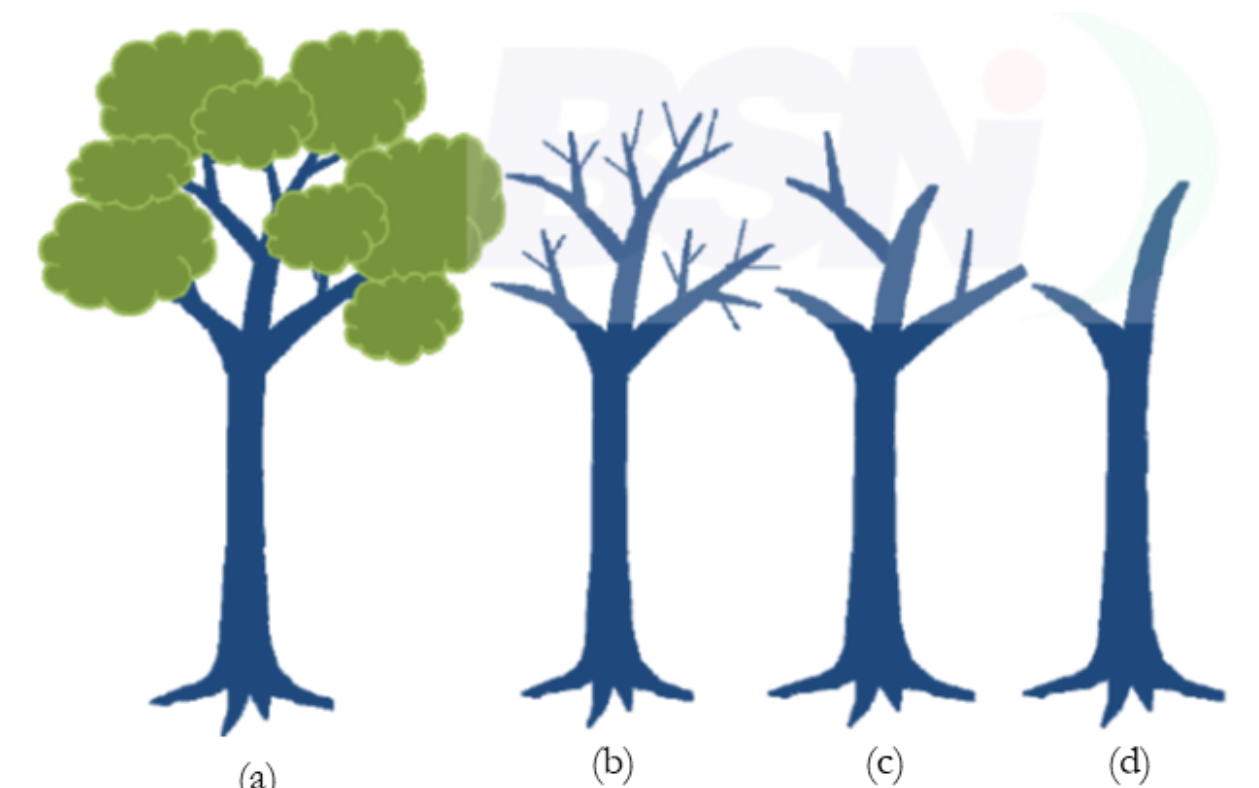

Figure 3. Standing deadwood category of individual tree according to BSN (2011), (a) Living tree; (b) slight deadwood; (c) moderate deadwood; and (d) intense deadwood. This category is used for i.e. the carbon offset factor of individual trees, 1 , $0.9,0.8$ and 0.7 , respectively.

\section{Data Analysis}

Data analysis was carried out in three phases. First, we consolidated the forest inventory data into a spreadsheet. We adopted an allometric equation from Chave et al. (2005) for the moist tropical forest ecosystem to calculate aboveground biomass of each tree since most of the forest stands on mineral soil. This allometric equation was selected to follow similar equation used by the Indonesia's FREL (Ministry of Environment and Forestry 2016) so that a direct comparison between results can be done. The allometric equation is expressed as follows:

$$
A G B=\exp \left(-1.499+2.148 \ln (D)+0.207(\ln (D))^{2}-0.0281(\ln (D))^{3}\right) \times W D
$$

where AGB is aboveground biomass (in $\mathrm{kg}$ ), $\mathrm{D}$ is $\mathrm{dbh}$ (in $\mathrm{cm}$ ), and WD is wood density (in $\mathrm{g} / \mathrm{cm}^{3}$ ). Wood density for each species was derived from International Centre for Research in Agroforestry (ICRAF) wood density database (http://db.worldagroforestry.org/wd). When no botanical identification was available, we used 0.66 as a default wood density referred to Biomass Conversion and Expansion Factor (BCEF) for tropical forest (IPCC 2006). The carbon offset factor (0.9; 0.8 or 0.7) was multiplied to the AGB of a single dead tree (using a similar allometric equation). Aboveground biomass estimates were converted into carbon mass (C) by multiplying AGB with 0.47 (IPCC 2006).

Second, statistical analyses were performed to examine forest stand and forest carbon stock characteristics in the study area. This includes mean, standard deviation, and sampling error estimates as described in Table 1. ANOVA was used to see the significant difference between AGC and geo- 
Table 1. Statistical analysis of the sample plot data. Uncertainty of estimates is characterized by Sampling Error (SE).

\begin{tabular}{|c|c|c|c|c|c|c|c|c|}
\hline \multirow[b]{2}{*}{$\begin{array}{c}\text { Forest } \\
\text { Cover type }\end{array}$} & \multicolumn{8}{|c|}{ Statistical Analysis } \\
\hline & $\operatorname{Mean}\left({ }^{M j}\right)$ & $\begin{array}{c}\text { Standard } \\
\text { deviation }(\mathrm{SD})\end{array}$ & $\begin{array}{c}\text { Sample } \\
\text { Count (n) }\end{array}$ & $\begin{array}{c}\text { t-statistic at } \\
95 \%(\mathrm{t})\end{array}$ & $\begin{array}{c}\text { Confidence } \\
\text { Interval }\end{array}$ & $\begin{array}{l}\text { Lower } \\
\text { Bound }\end{array}$ & $\begin{array}{l}\text { Upper } \\
\text { Bound }\end{array}$ & $\begin{array}{l}\text { Sampling } \\
\text { Error (\%) }\end{array}$ \\
\hline $\begin{array}{l}\text { Forest } \\
\text { type-j }\end{array}$ & $\frac{1}{n} \sum_{i=1}^{n} M i$ & $\sqrt{\frac{1}{n-1} \sum_{i=1}^{n}(M i+M j)^{2}}$ & $\begin{array}{c}3 \\
5 \\
8 \\
10 \\
50 \\
100 \\
\infty\end{array}$ & $\begin{array}{l}4,30 \\
2,78 \\
2,37 \\
2,26 \\
2,01 \\
1,98 \\
1,96\end{array}$ & $\frac{S D \times t}{\sqrt{n}}$ & $M j-C I$ & $M j+C I$ & $\frac{C I}{M j} \times 100 \%$ \\
\hline
\end{tabular}

$M i$ is the amount of aboveground carbon stock (in $\mathrm{tC} / \mathrm{ha}$ ) of cluster plot $-i$ in forest type $-j, \mathrm{n}$ is the number of plots in forest type-j.

graphic variables (i.e. elevation and forest cover types). The analysis was divided into two approaches. The first approach was that the forest in the study area is categorized into one forest category (i.e. natural forest). The second approach was that the forest in the study area is categorized into dryland natural primary forest (DPF) and dryland natural secondary forest (DSF), following the land cover category of the Ministry of Environment and Forestry (MoEF).

Third, we estimated the total AGC stock in the forest of BTNP by multiplying the total forest cover area (in ha) and the AGC (in tC/ha) under the two approaches earlier.

\section{RESULTS AND DISCUSSION}

\section{Results}

We recorded 14,127 individual trees with dbh (diameter at breast height) ranging from $5 \mathrm{~cm}$ to $295 \mathrm{~cm}$. There were 600 individuals classified as unidentified, and other individuals could be identified at least up to the family name. Dipterocarpaceae was the dominant family with 32 total species and 2,572 individuals.

\section{Forest stand characteristic}

The distribution of basal area and AGC of sample plots by diameter class is described in Figure 4. The fifth biggest contribution for AGC stock was made by 30 to 70 of diameter classes. These diameter classes accounted for more than $50 \%$ of the AGC of the sample plots. Big trees (diameter class more than $150 \mathrm{~cm}$ ) contributed less than $10 \%$ of the overall AGC stock of the sample plots. Overall, the average percentage of AGB and deadwood that constitutes AGC was $96.5 \%$ and $3.5 \%$, respectively.

Figure 5 describes the profile of stand basal area against AGC of the sampling plots. The relationship between basal area and AGC stock was relatively linear. Some plots possessed a higher basal area but resulted in low carbon stock because the plots were dominated by low to moderate wood density tree species. 


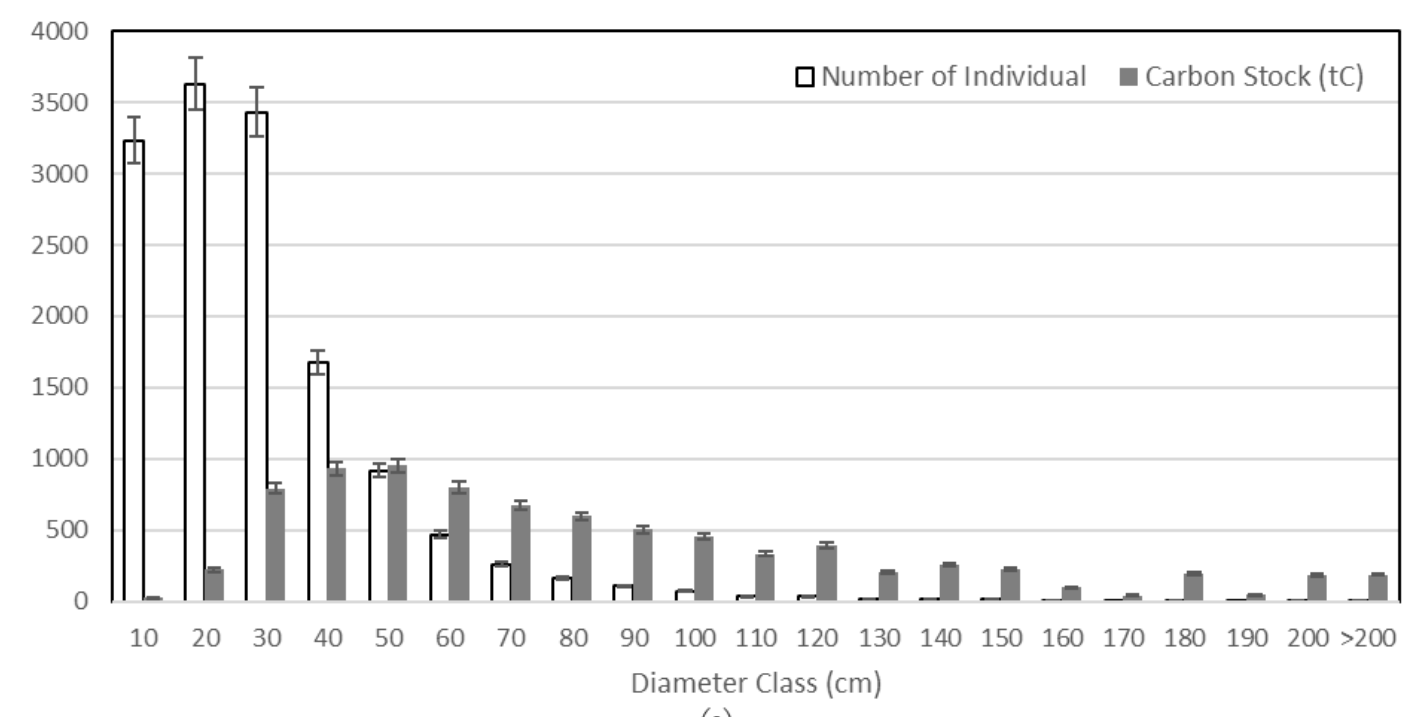

(a)

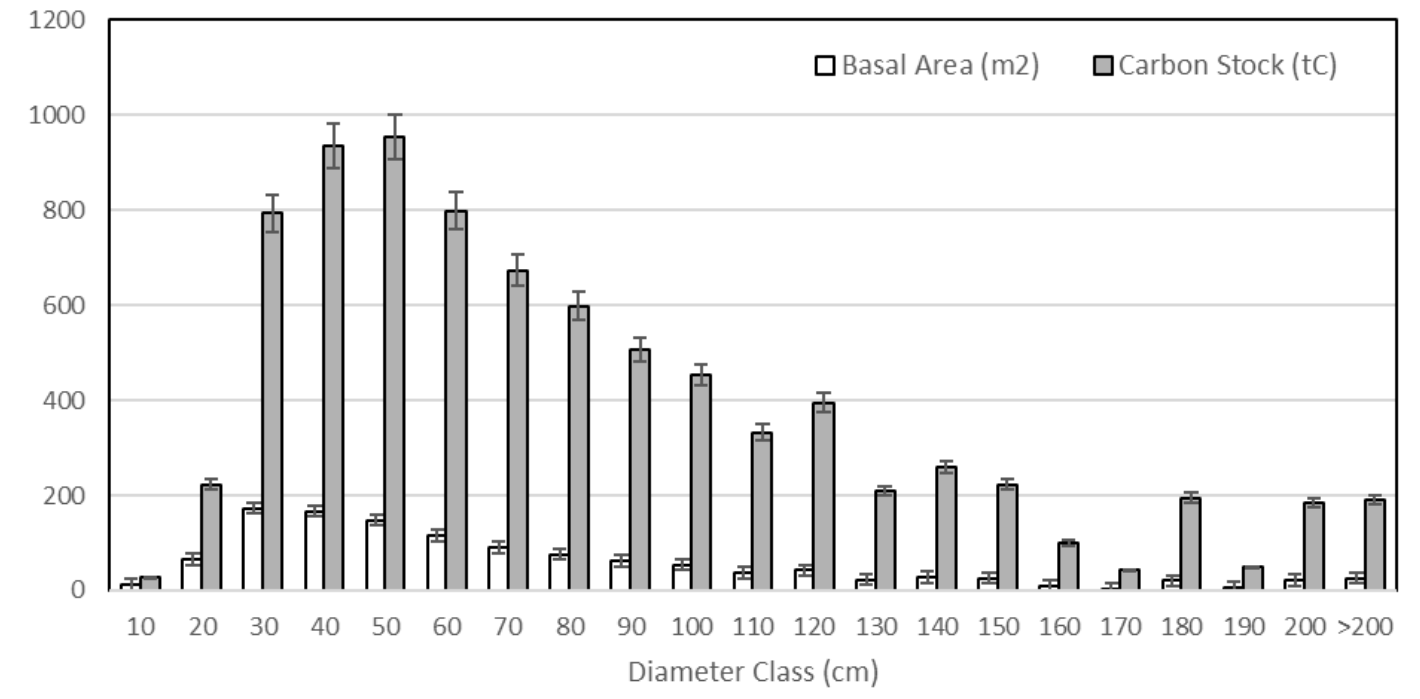

(b)

Figure 4. The data distribution of number of individual and AGC (a); and basal area and AGC (b) in the sample plots by diameter class. Each unit of measurements is presented in parentheses.

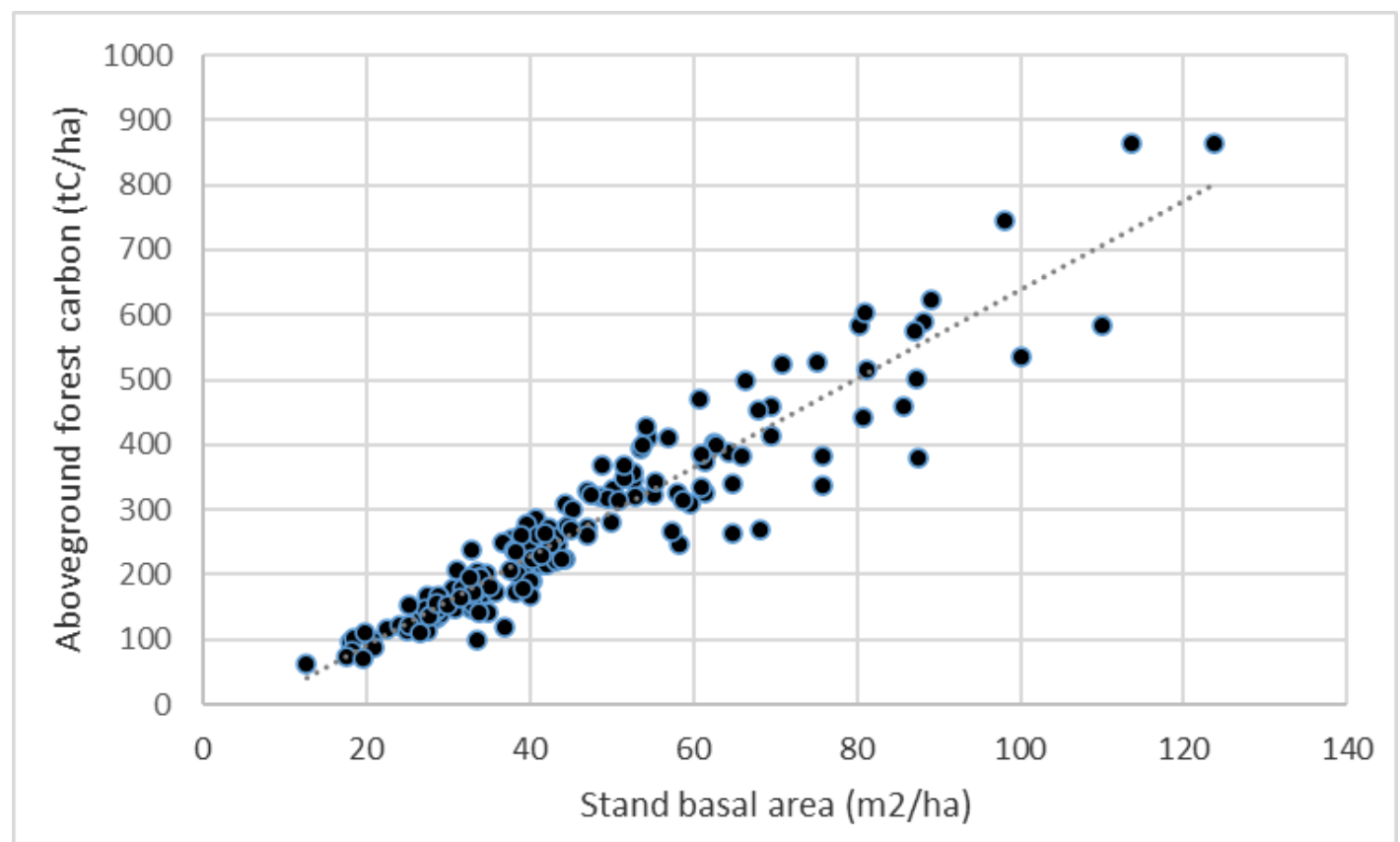

Figure 5. The profile of stand basal area against aboveground carbon stock of the sampling plots. The line represents a linear regression $\left(\mathrm{R}^{2}=0.8919, \mathrm{~F} 1,166=1370, \mathrm{P}<0.0001\right)$. 
The characteristic of sample plots with regard to elevation was described in Table 2. Most of the plots were established at $100-200 \mathrm{~m}$ asl elevation, while only one plot was set up below $100 \mathrm{~m}$ asl elevation (Table 3). Both basal area and carbon stock had a relatively similar increasing trend until $200-300 \mathrm{~m}$ asl, but then decreasing pattern until the highest elevation (above $400 \mathrm{~m}$ asl). However, ANOVA did not show a significant relation among elevation and aboveground forest carbon, where $\operatorname{Pr}(>\mathrm{F})$ was 0.1825 , and the $F$ value was 1.5783 .

\section{Aboveground carbon stock}

The First approach of AGC estimates resulted in 269.25 [247.07; 291.43] tC/ha with $8.24 \%$ of sampling error (SE) (Table 3). By the Second approach, AGC estimates in DPF resulted 287.03 [258.80; 315.26] tC/ha, while DSF resulted 230.67 [197.82; 263.52] tC/ha. ANOVA showed significant relation among forest types (DPF and DSF) and aboveground forest carbon, where $\operatorname{Pr}(>\mathrm{F})$ was 0.0202 , and the $\mathrm{F}$ value was 5.4987. However, SE estimates were rising into $9.84 \%$ and $14.24 \%$ of DPF and DSF, respectively.

Total AGC in the study area using the first and second approaches are presented in Table 4. The total forested area in BTNP based on the land cover map of 2016 was 133,051 ha which includes 126,992 ha of DPF and 6,059 ha of DSF. Using the first approach, the estimate of total AGC was lower than the second approach, i.e. 35,823,639 tC and 37,847,600 tC for first and second approaches.

Table 2. The characteristic of sample plots about elevation. Lower and upper are the $95 \%$ confidence interval (CI).

\begin{tabular}{cccccccc}
\hline \multirow{2}{*}{$\begin{array}{c}\text { Height } \\
(\mathrm{m} \text { asl })\end{array}$} & $\begin{array}{c}\text { Number of } \\
\text { Plot }\end{array}$ & \multicolumn{3}{c}{ Basal Area $\left(\mathrm{m}^{2} / \mathrm{ha}\right)$} & \multicolumn{3}{c}{ Carbon Stock (tC/ha) } \\
\cline { 3 - 8 } & 1 & Mean & Lower & Upper & Mean & Lower & Upper \\
\hline below 100 & 68.1 & NA & NA & 268.8 & NA & NA \\
$100-200$ & 77 & 45.5 & 43.4 & 47.6 & 259.5 & 230.0 & 289.1 \\
$200-300$ & 61 & 49.3 & 44.5 & 54.1 & 299.9 & 256.8 & 343.0 \\
$300-400$ & 24 & 40.4 & 30.9 & 49.8 & 240.5 & 184.9 & 296.1 \\
$400-500$ & 5 & 33.6 & 13.5 & 53.8 & 183.1 & 111.2 & 255.0 \\
\hline
\end{tabular}

Table 3. Statistical analysis of aboveground forest carbon (AGC) stock.

\begin{tabular}{|c|c|c|c|c|c|c|c|c|}
\hline \multirow[b]{2}{*}{$\begin{array}{l}\text { Forest Cover } \\
\text { type }\end{array}$} & \multicolumn{8}{|c|}{ Statistical Analysis } \\
\hline & $\begin{array}{l}\text { Mean } \\
\left({ }^{x j}\right)\end{array}$ & $\begin{array}{l}\text { Standard } \\
\text { Deviation } \\
\text { (SD) }\end{array}$ & $\begin{array}{l}\text { Sample } \\
\text { Count } \\
\text { (n) }\end{array}$ & $\begin{array}{c}\text { t-statistic at } \\
95 \%(\mathrm{t})\end{array}$ & $\begin{array}{l}\text { Confidence } \\
\text { Interval (CI) }\end{array}$ & $\begin{array}{l}\text { Lower } \\
\text { Bound }\end{array}$ & $\begin{array}{l}\text { Upper } \\
\text { Bound }\end{array}$ & $\begin{array}{l}\text { Sampling } \\
\text { Error }(\%)\end{array}$ \\
\hline \multicolumn{9}{|l|}{ First approach } \\
\hline Forested area & 269.25 & 146.69 & 168 & 1.96 & 22.18 & 247.07 & 291.43 & 8.24 \\
\hline \multicolumn{9}{|l|}{ Second approach } \\
\hline DPF & 287.03 & 154.46 & 115 & 1.96 & 28.23 & 258.80 & 315.26 & 9.84 \\
\hline DSF & 230.67 & 120.77 & 53 & 1.98 & 32.85 & 197.82 & 263.52 & 14.24 \\
\hline
\end{tabular}


Table 4. Aboveground forest carbon (AGC) stored in Bukit Tigapuluh National Park

\begin{tabular}{|c|c|c|c|c|c|c|c|}
\hline \multirow{2}{*}{ Land cover category } & \multirow{2}{*}{ Area (ha) } & \multicolumn{3}{|c|}{ Carbon density/stock (tC/ha) } & \multicolumn{2}{|c|}{ Total carbon stock (tC) } & \multirow[b]{2}{*}{ Upper } \\
\hline & & Mean & Lower & Upper & Mean & Lower & \\
\hline \multicolumn{8}{|l|}{ First approach } \\
\hline Forested area & 133,051 & 269.25 & 247.07 & 291.43 & $35,823,639$ & $32,872,312$ & $38,774,966$ \\
\hline \multicolumn{8}{|l|}{ Second approach } \\
\hline DPF & 126,992 & 287.03 & 258.80 & 315.26 & $36,449,909$ & $32,864,849$ & $40,034,969$ \\
\hline DSF & 6,059 & 230.67 & 197.82 & 263.52 & $1,397,691$ & $1,198,664$ & $1,596,717$ \\
\hline Total & 133,051 & & & & $37,847,600$ & $34,063,514$ & $41,631,686$ \\
\hline
\end{tabular}

\section{Discussion}

\section{Forest stand and carbon stock characteristics}

We evidenced a high diversity of vegetation in the study area by 59 families of trees ( $5 \mathrm{~cm}$ up, i.e. including saplings and poles) covering at least 331 species. The forest ecosystem in BTNP was dominated by the dipterocarp family as the flagship of tropical lowland rainforest in South East Asia (Kuswanda \& Barus 2019; Laumonier et al. 2010; Manuri et al. 2016; Yamakura et al. 1986). This forest showed a decent condition of vegetation structure which is characterized by an inverted J graph (negative exponential) of the distribution of the number of individuals by diameter class. This structure is the characteristic of a stable natural forest, where small trees that make up the ecosystem tend to be more dense than large trees (Gunawan et al. 2011). This trend is unlike the distribution of basal area and AGC, where the tendency is more like a normal curve (inverted bell) with the highest value in the diameter class $30-70 \mathrm{~cm}$. Stand characteristics like this indicate a natural regeneration process that runs properly where the number of saplings and poles are abundant, and the highest productivity is in the middle classes of diameter which then decreases in the larger diameter classes.

Our analysis of carbon stock estimation showed that using a single class of forest (i.e. natural forest) is more consistent, as demonstrated by low sample error compare to that separating the natural forest class into DPF and DSF (higher SE). This result revealed that detailing forest cover into more specific forest classes in the study area did not improve estimates' uncertainty. There are two reasons for this. The first reason is that the decreasing number of plots in DPF and DSF, increases the data disparity as indicated by the increase of SE. The second reason is the differentiation between DSF and DPF are based only on the visual characteristic of remote sensing data, so it was not related to the type of carbon stock in each forest class.

Ministry of Environment and Forestry (2016) stated that the difference between DPF and DSF is merely related to an exhibit sign of logging activities indicated by patterns and spotting of logging (appearance of roads and logged-over patches), hence difficult to distinguish through Landsat 8 image although some areas of BTNP were a logging concession in the past (Kuswanda \& Barus 2019). So, it is possible that DPF and DSF does not necessarily relate to the actual amount of carbon stocks. On the other hand, 
Romijn et al. (2013) pointed out that countries shall select the major GHG emissions from land-use changes (e.g. forest cover change) through robust methodology and definitions. This allows them to make a land cover classification that differentiates between different forest types and other important land cover classes. Therefore, to decide forest or land cover classification, attention on how carbon stock has been included into consideration needs to be addressed.

We selected the first approach based on the above considerations. Using this selection, we estimated AGC stock in BTNP is $269.2 \pm 22.2 \mathrm{tC} / \mathrm{ha}$. In total, forested area in BTNP stored 35,823,639 $\pm 2,951,071$ tC of AGC. This result was higher than other studies conducted in non-protected area (e.g. Laumonier et al. 2010; Ministry of Environment and Forestry 2016; Rutishauser et al. 2013; Slik et al. 2010; Yamakura et al. 1986), but lower estimates than other studies located in the protected area, i.e. Gunung Palung National Park, West Kalimantan (Paoli et al. 2008) (Table 5). Our results were higher than Avitabile et al. (2016), which produced a pan-tropical biomass map covering Bukit Tigapuluh National Park.

Table 5. Forest stand and carbon stock characteristics in various tropical lowland evergreen forests. Each unit of measurements is presented in parentheses.

\begin{tabular}{|c|c|c|c|c|c|c|c|}
\hline No. & Locality & Methodology & $\begin{array}{l}\text { Stand } \\
\text { Basal Area } \\
(\mathrm{m} 2 / \mathrm{ha})\end{array}$ & $\begin{array}{l}\text { Forest } \\
\text { Carbon (tC/ } \\
\text { ha) }\end{array}$ & $\begin{array}{l}\text { Range of } \\
\text { dbh }(\mathrm{cm})\end{array}$ & $\begin{array}{l}\text { Sample } \\
\text { area }\end{array}$ & Authors \\
\hline 1. & $\begin{array}{l}\text { Borneo (Sebulu, } \\
\text { East Kalimantan) }\end{array}$ & $\begin{array}{l}\text { Terrestrial sampling for } \\
\text { AGB, allometric equation } \\
\text { (Ogawa \& Kira 1977) }\end{array}$ & 36.8 & 239.23 & $\leq 152$ & $1 \mathrm{ha}$ & $\begin{array}{l}\text { Yamakura et al. } \\
\text { (1986) }\end{array}$ \\
\hline 2. & $\begin{array}{l}\text { Sumatera Land- } \\
\text { scape (Jambi, } \\
\text { Bengkulu, South } \\
\text { Sumatra, } \\
\text { Lampung) }\end{array}$ & $\begin{array}{l}\text { Terrestrial sampling for } \\
\text { AGB, allometric equation } \\
\text { (Brown 1997; Yamakura } \\
\text { et al. 1986) }\end{array}$ & $\begin{array}{l}31.7[31.2 \\
32.2]\end{array}$ & $\begin{array}{l}180 \\
{[135 ; 240)}\end{array}$ & $10-210$ & $70.2 \mathrm{ha}$ & $\begin{array}{l}\text { Laumonier et al. } \\
\text { (2010) }\end{array}$ \\
\hline 3. & $\begin{array}{l}\text { East Kalimantan, } \\
\text { Pasir Mayang } \\
\text { Sumatra }\end{array}$ & $\begin{array}{l}\text { Terrestrial sampling for } \\
\text { AGB, allometric equation } \\
\text { (Chave et al. 2005) }\end{array}$ & 30.1 & $\begin{array}{l}160 \\
148 ; 164)\end{array}$ & $10-140$ & $12 \mathrm{ha}$ & $\begin{array}{l}\text { Rutishauser et al. } \\
\text { (2013) }\end{array}$ \\
\hline 4. & $\begin{array}{l}\text { NFI Sumatra } \\
\text { (DPF) }\end{array}$ & $\begin{array}{l}\text { Terrestrial sampling for } \\
\text { AGB, allometric equation } \\
\text { (Chave et al. 2005) }\end{array}$ & NA & $\begin{array}{l}135 \\
{[125 ; 145]}\end{array}$ & NA & $92 \mathrm{ha}$ & $\begin{array}{l}\text { Ministry of Environ- } \\
\text { ment and Forestry } \\
\text { (2016) }\end{array}$ \\
\hline 5. & $\begin{array}{l}\text { NFI Sumatera } \\
\text { (DSF) }\end{array}$ & $\begin{array}{l}\text { Terrestrial sampling for } \\
\text { AGB, allometric equation } \\
\text { (Chave et al. 2005) }\end{array}$ & NA & $\begin{array}{l}85.6 \\
{[80.9 ; 90.3]}\end{array}$ & NA & 265 ha & $\begin{array}{l}\text { Ministry of Environ- } \\
\text { ment and Forestry } \\
\text { (2016) }\end{array}$ \\
\hline 6. & Borneo & $\begin{array}{l}\text { Terrestrial sampling for } \\
\text { AGB, allometric equation } \\
\text { (Chave et al. 2005) }\end{array}$ & $26-49$ & 214.8 & $\geq 10$ & 83 plot & Slik et al. (2010) \\
\hline 7. & $\begin{array}{l}\text { Gunung Palung } \\
\text { NP, West } \\
\text { Kalimantan }\end{array}$ & $\begin{array}{l}\text { Terrestrial sampling for } \\
\text { AGB, allometric equation } \\
\text { (Brown 1997; Chave et al. } \\
\text { 2005) }\end{array}$ & $39.6 \pm 1.4$ & $\begin{array}{l}292.3 \\
{[276.8 ; 307.8]}\end{array}$ & $\geq 10$ & 4.8 ha & Paoli et al. (2008) \\
\hline 8. & $\begin{array}{l}\text { Bukit Tigapuluh } \\
\text { NP }\end{array}$ & $\begin{array}{l}\text { Data fusion approach of } \\
\text { two pantropical biomass } \\
\text { maps }\end{array}$ & NA & $\begin{array}{l}160 \\
{[114 ; 206]}\end{array}$ & NA & NA & Avitabile et al. (2016) \\
\hline 9. & $\begin{array}{l}\text { Bukit Tigapuluh } \\
\text { NP, Riau - Jambi }\end{array}$ & $\begin{array}{l}\text { Terestrial sampling plot } \\
\text { and spatial data }\end{array}$ & 45.93 & $\begin{array}{l}269.2 \\
{[247.1 ; 291.4]}\end{array}$ & $5-295$ & $33.6 \mathrm{ha}$ & This study \\
\hline
\end{tabular}


The three highest estimates on forest carbon stock were Paoli et al. (2008), this study, and Yamakura et al. (1986), while the lowest estimates were from the (Ministry of Environment and Forestry 2016). A conservative estimate from (Ministry of Environment and Forestry 2016) probably occurred because of their data selection mechanism. (Ministry of Environment and Forestry 2016) stated that the data validation included, among others, checking measurement data through abnormality filtering of $\mathrm{DBH}$ and species name of individual trees in the plots. This filtering mechanism can reduce data variation, thus reducing the number of oversized trees. However, as estimates from (Ministry of Environment and Forestry 2016) was the lowest (both DPF and DSF), a re-enumeration of this national carbon stock with newly available data is advisable, among others, with the inclusion of public participation such as university, research center and other non-state actors (e.g. Boissière et al. 2017).

\section{Implication to the management of protected area}

This study and Paoli et al. (2008) supported the argument that protected areas possess a higher figure of carbon stock compared to other forest management unit. The national government administers national parks in Indonesia strictly prohibits the access of people to the parks to ensure the integrity of forest ecosystems (Harada et al. 2015), so a purely intact forest or an old secondary forest are typically found. Collins and Mitchard (2017) have estimated carbon emissions in the large forest protected areas in tropical countries $(\mathrm{N}=2018)$ and found that $36 \pm 16 \mathrm{Pg} \mathrm{C}$ is stored in protected area's trees, representing $14.5 \%$ of all tropical forest biomass carbon. These results suggest that protected areas have been a successful instrument in protecting carbon biomass, thus a subset causing a disproportionately high share of emissions should be an urgent priority for management interventions.

Protected areas aim at protecting multiple ecosystem services (Collins \& Mitchard 2017). Apart from its role in biodiversity conservation, the benefits they deliver to society include water, food and medicine, and they also provide important recreational, educational, spiritual and cultural places (Deguignet et al. 2017). We have demonstrated that protected areas in the tropics secure exceptionally high amount of AGC, which is very important to be conserved in the perspective of climate change mitigation. The high amount of AGC stock in the protected areas shall be very important assets for conducting the role of conservation for REDD + . Therefore, the management of BTNP shall enlarge their perspectives on climate change mitigation action apart from merely biodiversity conservation and life-support system. REDD+ readiness for protected areas needs to be completed as soon as possible since REDD+ has been a commitment of Indonesia's Government for conducting Nationally Determined Contribution (Republic of Indonesia 2016).

Many national parks in Indonesia have frequently been suffering from conflicts between government and local people (Harada et al. 2015). 
REDD+ initiatives may become a way to tackle social and political problems and guarantee people's right to use and manage forests. REDD+ initiatives are expected to resolve such forest tenure issues, which may become a key precondition to implementing REDD+ projects effectively. Harada et al. (2015) confirmed that the REDD+ demonstration activities (DA) project in Meru Betiri NP could secure land use inside the national park and the participation of local people in the REDD+ DA project in the park, which national regulations in Indonesia had strictly prohibited. Consequently, the project in the national park could successfully introduce alternative livelihoods to improve income, particularly for economically disadvantaged people, by implementing a rehabilitation program with agroforestry while conserving forests. Harada et al. (2015) also demonstrated the necessity of further discussion of effective benefit-sharing of REDD + incentive while realizing local participation in REDD+ projects and improving local livelihoods. These project outputs can become a model for collaborative forest management with multiple stakeholders in different national parks, such as Bukit Tigapuluh National Park.

\section{CONCLUSION}

Stand characteristics in Bukit Tigapuluh National Park indicate that the natural regeneration process is going well. The highest AGC was found in the middle diameter class which then decreases in the larger diameter classes. This stable forest ecosystem secured a significant forest carbon stock estimated as 269.25 [247.07; 291.43] tC/ha or in total 35,823,639 [32,872,312, $38,774,966$ t tC being stored in approximately 133,051 hectares of the tropical rain forest. This result was higher than other studies in non-protected areas, but was lower than other studies in protected areas, such as Gunung Palung National Park, West Kalimantan. This study and Paoli et al. (2008) supported the argument that protected areas possess higher carbon stock figures compared to other non-protected forest management units. The high amount of forest carbon biomass in the protected areas shall be very important assets for conducting the role of conservation for REDD + . Therefore, the management of BTNP shall enlarge their perspectives on climate change mitigation aside from merely biodiversity conservation and life-support system.

\section{AUTHORS CONTRIBUTION}

A.D. is lead researcher, conducting overall strategy to conduct this research from planning, data collection, analysis and writing report and paper. Z.W. is giving general suggestion and managing the field data collection. E.M. is analyzing spatial data. A.V. is giving suggestion and English proofread. M.I.F. is giving suggestion on database and data analysis. G.D.W. is giving suggestion on data analysis and discussion. B.W. is giving suggestion the data analysis and discussion especially on National Park Management. T.R. is giving suggestion on the data analysis and discussion on carbon inventory. S.T. is giving suggestion on the general part of the manuscript and English proofread. 


\section{ACKNOWLEDGMENTS}

We are grateful to the Balai Taman Nasional Bukit Tigapuluh for supporting the ground survey of carbon measurement and data entry to facilitate this study in collaboration with WWF Indonesia. This study was funded by WWF France.

\section{CONFLICT OF INTEREST}

No competing interest among author and co-authors.

\section{REFERENCES}

Avitabile, V. et al., 2016. An integrated pan-tropical biomass map using multiple reference datasets. Global Change Biology, 22(4), pp.1406-1420. doi: 10.1111/gcb.13139.

Baraloto, C. et al., 2013. Rapid Simultaneous Estimation of Aboveground Biomass and Tree Diversity Across Neotropical Forests: A Comparison of Field Inventory Methods. Biotropica, 45(3), pp.288-298. doi: 10.1111/btp.12006.

Boissière, M. et al., 2017. The feasibility of local participation in Measuring, Reporting and Verification (PMRV) for REDD+ B. Bond-Lamberty, ed. PLOS ONE, 12(5), p.e0176897. doi: 10.1371/ journal.pone.0176897.

Brofeldt, S. et al., 2014. Community Monitoring of Carbon Stocks for REDD+: Does Accuracy and Cost Change over Time? Forests, 5(8), pp.1834-1854. doi: 10.3390/f5081834.

Brown, S., 1997. Estimating biomass and biomass change of tropical forests: a primer, Rome: Food and Agriculture Organization of the United Nations.

BSN, 2011. SNI 7724:2011 Pengukuran dan penghitungan cadangan karbon -Pengukuran lapangan untuk penaksiran cadangan karbon hutan (ground based forest carbon accounting).

Bukit Tigapuluh Wildlife Protection Unit, 2017. Quarterly report: January March 2017.

Chave, J. et al., 2005. Tree allometry and improved estimation of carbon stocks and balance in tropical forests. Oecologia, 145(1), pp.87-99. doi: 10.1007/s00442-005-0100-x.

Collins, M.B. \& Mitchard, E.T.A., 2017. A small subset of protected areas are a highly significant source of carbon emissions. Scientific Reports, 7(1). doi: 10.1038/srep41902.

Deguignet, M. et al., 2017. Measuring the extent of overlaps in protected area designations D. Hyrenbach, ed. PLOS ONE, 12(11), p.e0188681. doi: 10.1371/journal.pone.0188681.

FAO, 2007. Brief on national forest inventory NFI - Indonesia., p.14.

Gardner, T.A. et al., 2012. A framework for integrating biodiversity concerns into national REDD+ programmes. Biological Conservation, 154, pp.6171. doi: 10.1016/j.biocon.2011.11.018. 
GOFC-GOLD, 2014a. A sourcebook of methods and procedures for monitoring and reporting anthropogenic greenhouse gas emissions and removals associated with deforestation, gains and losses of carbon stocks in forests remaining forests, and forestation GOFC-GOLD Report version COP20-1., GOFC-GOLD Land Cover Project Office, hosted by Wageningen University, The Netherlands.

GOFC-GOLD, 2014b. A sourcebook of methods and procedures for monitoring and reporting anthropogenic greenhouse gas emissions and removals associated with deforestation, gains and losses of carbon stocks in forests remaining forests, and forestation GOFC-GOLD Report version COP20-1., GOFC-GOLD Land Cover Project Office, hosted by Wageningen University, The Netherlands.

Government of Indonesia, 1999. Undang-Undang No. 41 Tahun 1999 tentang Kehutanan.

Gunawan, W. et al., 2011. Analysis of Vegetation Structure and Composition toward Restoration Efforts of Gunung Gede Pangrango National Park Forest Area. Jurnal Pengelolaan Sumberdaya Alam dan Lingkungan, 1(2), pp.93-105. doi: https://doi.org/10.29244/jpsl.1.2.93.

Harada, K. et al., 2015. How Can Social Safeguards of REDD+ Function Effectively Conserve Forests and Improve Local Livelihoods? A Case from Meru Betiri National Park, East Java, Indonesia. Land, 4(1), pp.119-139. doi: 10.3390/land4010119.

Henttonen, H.M. \& Kangas, A., 2015. Optimal plot design in a multipurpose forest inventory. Forest Ecosystems, 2(1), p.31. doi: 10.1186/s40663-0150055-2.

Indonesia Forest Climate Alliance (IFCA), 2007. REDDI: REDD Methodology and Strategies: Summary for Policy Makers, Jakarta, Indonesia: The Ministry of Forestry.

IPCC, 2006. 2006 IPCC Guidelines for National Greenhouse Gas Inventories, Hayama, Japan: The Institute for Global Environmental Strategies (IGES).

IUCN, 2010. 50 years of working for protected areas. IUCN, Gland, Switzerland. 2010., Gland, Switzerland: IUCN.

Kuswanda, W. \& Barus, S.P., 2019. Characteristic and Diversity Vegetation of Bukit Tiga Puluh National Park as Dietary Sources for Reintroduced Sumatran Orang Utan (Pongo abelii Lesson). Buletin Plasma Nutfah, 25 (1), p.63. doi: 10.21082/blpn.v25n1.2019.p63-76.

Laumonier, Y. et al., 2010. Landscape-scale variation in the structure and biomass of the hill dipterocarp forest of Sumatra: Implications for carbon stock assessments. Forest Ecology and Management, 259(3), pp.505-513. doi: 10.1016/j.foreco.2009.11.007.

Luskin, M.S., Albert, W.R. \& Tobler, M.W., 2017. Sumatran tiger survival threatened by deforestation despite increasing densities in parks. Nature Communications, 8(1). doi: 10.1038/s41467-017-01656-4.

Manuri, S. et al., 2016. Improved allometric equations for tree aboveground biomass estimation in tropical dipterocarp forests of Kalimantan, Indonesia. Forest Ecosystems, 3(1). doi: 10.1186/s40663-016-0087-2. 
Manuri, S. et al., 2017. Effect of species grouping and site variables on aboveground biomass models for lowland tropical forests of the IndoMalay region. Annals of Forest Science, 74(1). doi: 10.1007/s13595-0170618-1.

Marshall, A.R. et al., 2012. Measuring and modelling above-ground carbon and tree allometry along a tropical elevation gradient. Biological Conservation, 154, pp.20-33. doi: 10.1016/j.biocon.2012.03.017.

Ministry of Environment and Forestry, 2016. National Forest Reference Emission Level for Deforestation and Forest Degradation: In the Context of Decision 1/ CP.16 para 70 UNFCCC (Encourages developing country Parties to contribute to mitigation actions in the forest sector), Jakarta, Indonesia: Directorate General of Climate Change (DG-PPI), The Ministry of Environment and Forestry.

Ogawa, H. \& Kira, T., 1977. Methods of estimating forest biomass. In T. Shidei \& T. Kira (eds), Primary productivity of Japanese forest. JIBP Synthesis 16. Tokyo: Univ. of Tokyo Press, pp. 15-25.

Paoli, G.D., Curran, L.M. \& Slik, J.W.F., 2008. Soil nutrients affect spatial patterns of aboveground biomass and emergent tree density in southwestern Borneo. Oecologia, 155(2), pp.287-299. doi: 10.1007/s00442007-0906-9.

Petrokofsky, G. et al., 2012. Comparison of methods for measuring and assessing carbon stocks and carbon stock changes in terrestrial carbon pools. How do the accuracy and precision of current methods compare? A systematic review protocol. Environmental Evidence, 1(1), p.6. doi: 10.1186/2047-2382-1-6.

Picard, N. et al., 2018. Plot-level variability in biomass for tropical forest inventory designs. Forest Ecology and Management, 430, pp.10-20. doi: 10.1016/j.foreco.2018.07.052.

Pramudya, E.P., Hospes, O. \& Termeer, C.J.A.M., 2018. The disciplining of illegal palm oil plantations in Sumatra. Third World Quarterly, 39(5), pp.920-940. doi: 10.1080/01436597.2017.1401462.

Pusat Data dan Informasi KLHK, 2017. Statistik Kementerian Lingkungan Hidup dan Kebutanan Tabun 2016, Jakarta, Indonesia: Kementerian Lingkungan Hidup dan Kehutanan.

Republic of Indonesia, 2016. First Nationally Determined Contribution Republic of Indonesia.

Romijn, E. et al., 2013. Exploring different forest definitions and their impact on developing REDD+ reference emission levels: A case study for Indonesia. Environmental Science \& Policy, 33, pp.246-259. doi: 10.1016/j.envsci.2013.06.002.

Rutishauser, E. et al., 2013. Generic allometric models including height best estimate forest biomass and carbon stocks in Indonesia. Forest Ecology and Management, 307, pp.219-225. doi: 10.1016/j.foreco.2013.07.013. 
Shah, P. \& Baylis, K., 2015. Evaluating Heterogeneous Conservation Effects of Forest Protection in Indonesia D. Hui, ed. PLOS ONE, 10(6), p.e0124872. doi: 10.1371/journal.pone.0124872.

Sitompul, A. \& Pratje, P. eds., 2009. The Bukit Tigapulub Ecosystem Conservation Implementation Plan, Bukit Tigapuluh National Park, Directorate General Forest Protection and Nature Conservation.

Slik, J.W.F. et al., 2010. Environmental correlates of tree biomass, basal area, wood specific gravity and stem density gradients in Borneo's tropical forests: Forest carbon and structure gradients. Global Ecology and Biogeography, 19(1), pp.50-60. doi: 10.1111/j.1466-8238.2009.00489.x.

Yamakura, T. et al., 1986. Aboveground Biomass of Tropical Rain Forest Stands in Indonesian Borneo. Vegetatio, 68(2), pp.71-82. 